\title{
PENGARUH DISTANSI TERHADAP TINGKAT KEBISINGAN YANG BERSUMBER DARI BUNYI MESIN KENDARAAN (STUDI KASUS PADA JALAN SUPRAPTO KOTA BENGKULU)
}

\author{
Samsul Bahri ${ }^{1)}$, Ari Saputra ${ }^{1)}$, Makmun Reza Razali ${ }^{1{ }^{1}}$ \\ ${ }^{1)}$ Program Studi Teknik Sipil, Fakultas Teknik Universitas Bengkulu, \\ Jl. W.R. Supratman, Kandang Limun, Bengkulu 38371, Telp (0736) 344087 \\ Corresponding Author: sbahri1972@yahoo.co.id
}

\begin{abstract}
Abstrak
Kebisingan pada suatu ruas jalan disebabkan oleh bunyi mesin kendaraan yang melintas. Kebisingan dapat mengurangi kenyamanan lingkungan dan menimbulkan gangguan kesehatan pada manusia. Jarak obyek dengan sumber bunyi menentukan besaran dampak yang diterima. Penelitian ini bertujuan untuk mencari pengaruh distansi terhadap tingkat kebisingan yang bersumber dari bunyi mesin kendaraan. Penelitian dilakukan di Pusat Kota Bengkulu yaitu Jalan Suprapto. Pengamatan dilakukan di 2 segmen Jalan Suprapto dengan interval jarak $10 \mathrm{~m}$ arah tegak lurus sumber bunyi dengan jumlah 5 titik. Model matematis menggunakan pendekatan persamaan regresi linier. Distansi merupakan variabel bebas dan kebisingan merupakan variabel tidak bebas. Hasil penelitian menunjukkan bahwa hubungan antara jarak titik pengamatan dengan nilai kebisingan diperoleh persamaan $Y=-0,317 x+71,20$ dengan $R 2=0,984$.
\end{abstract}

Kata kunci: kebisingan, distansi, regresi

\begin{abstract}
Noise on a road is caused by the sound of a vehicle engine which is passing on. It can make the environment uncomfortable and the health problems in humans. The distance between the object and the sound source determines the magnitude of this impact. This study aims to look for the effect of the distance on noise levels that caused by vehicle engine sounds. The study was conducted in the central of Bengkulu City, Jalan Suprapto. Observations were made in 2 segments of Suprapto Road with $10 \mathrm{~m}$ distance intervals perpendicular to the sound source with a total of 5 points. The mathematical model uses the linear regression equation approach. Distance is an independent variable and noise is an independent variable. The results showed that, the relationship between the distance of the observation point and the noise value obtained equation $\mathrm{Y}=-0,317 \mathrm{x}+71,20$ with $R^{2}=0,984$.
\end{abstract}

Keywords: noise, distortion, regression 


\section{PENDAHULUAN}

Keramaian suatu kota ditandai oleh beberapa hal, diantaranya adalah meningkatnya jumlah kendaraan bermotor pada ruas jalan yang ada. Pergerakan kendaraan menimbulkan bunyi mesin yang keluar melalui knalpot maupun bunyi yang keluar dari klakson. Bunyi-bunyian yang dihasilkan oleh kendaraan memiliki tingkatan yang bervariasi. Pada level tertentu, bunyi kendaraan menimbulkan gangguan pada telinga manusia dalam bentuk suara bising.

Menurut Abbas (2008) transportasi adalah kegiatan pemindahan (muatan) atau penumpang dari satu tempat ke tempat yang lain. Menurut Tamin (2000), prasarana transportasi mempunyai dua peran utama, yaitu sebagai alat bantu untuk mengarahkan pembangunan di daerah perkotaan dan sebagai prasarana bagi pergerakan manusia dan barang yang timbul akibat adanya kegiatan di daerah perkotaan tersebut.

Menurut Undang-Undang RI No. 22 Tahun 2009, transportasi darat atau kendaraan adalah suatu sarana angkut di jalan yang terdiri atas kendaraan bermotor dan kendaraan tidak bermotor. Kendaraan bermotor adalah setiap kendaraan yang digerakkan oleh peralatan mekanik berupa mesin selain kendaraan yang berjalan di atas rel, terdiri dari kendaraan bermotor perseorangan dan kendaraan bermotor umum. Kendaraan tidak bermotor adalah kendaraan yang digerakkan oleh tenaga orang atau hewan.

\section{TINJAUAN PUSTAKA}

\section{Kecepatan Kendaraan}

Menurut Direktorat Jenderal Bina Marga (2014) dalam Pedoman Kapasitas Jalan Indonesia (PKJI), kecepatan tempuh adalah kecepatan rata-rata ruang (space mean speed) kendaraan sepanjang segmen jalan. Kecepatan tempuh dihitung dengan persamaan:

$\mathrm{V}_{\mathrm{T}}=\mathrm{L} / \mathrm{W}_{\mathrm{T}}$

Keterangan:

$\mathrm{L} \quad=$ Panjang segmen jalan $(\mathrm{km})$

$\mathrm{V}_{\mathrm{T}}=$ Kecepatan tempuh rata-rata $(\mathrm{km} / \mathrm{jam})$

$\mathrm{W}_{\mathrm{T}}=$ Waktu tempuh rata-rata (jam)

\section{Volume Lalu Lintas}

Menurut Luttinen (2004), volume lalu lintas adalah jumlah kendaraan yang melewati suatu titik pada suatu lajur atau jalan raya selama interval waktu tertentu. Volume dinyatakan dalam satuan kendaraan persatuan waktu, yang dinyatakan dengan persamaan:

$\mathrm{Q}=\mathrm{N} / \mathrm{T}$

Keterangan:

$\mathrm{Q}=$ Volume lalu lintas ( $\mathrm{skr} / \mathrm{jam}$ )

$\mathrm{N}=$ Jumlah kendaraan yang melewati tampang (kend/lajur)

$\mathrm{T}=$ Waktu pengamatan (jam)

Data volume kendaraan dihitung secara terpisah sesuai dengan golongan atau tipenya. Maka dari itu dalam proses perhitungan, data volume tersebut perlu dikalikan dengan koefisien satuan mobil penumpang (skr). Satuan kendaraan ringan disingkat skr adalah satuan kendaraan di dalam arus lalu lintas yang disetarakan dengan kendaraan ringan/mobil $\mathrm{p}$ enumpang dengan menggunakan ekivalensi kendaraan ringan (ekr) atau faktor pengali berbagai jenis kendaraan menjadi satu satuan yaitu skr, dimana besaran skr dipengaruhi oleh tipe/jenis kendaraan, dimensi kendaraan, dan kemampuan olah gerak.

Menurut Direktorat Jenderal Bina Marga (2014) dalam Pedoman Kapasitas Jalan 
Indonesia (PKJI), ekivalen kendaraan ringan (ekr) adalah faktor penyeragaman satuan dari beberapa tipe kendaraan dibandingkan terhadap kendaraan ringan sehubungan dengan pengaruhnya kepada karekteristik arus campuran. Nilai ekr ditentukan sebagai berikut: ekr kendaraan ringan $=1,0$ dan ekr sepeda motor $=0,5$. Data jumlah kendaraan dihitung dalam kendaraan/jam untuk setiap jenis kendaraan. Arus lalu lintas total dalam skr/jam dapat dihitung dengan rumus sebagai berikut:

$\mathrm{Qskr}=(\mathrm{ekrKR} \times \mathrm{KR})+(\mathrm{ekrSM} \times \mathrm{SM})$

Keterangan:

Qskr = Volume kendaraan bermotor (skr/jam)

ekrKR = Nilai ekivalen untuk kendaraan ringan $(1,0)$

ekr SM = Nilai ekivalen untuk sepeda motor $(0,5)$

$\mathrm{KR}=$ Notasi untuk kendaraan ringan

$\mathrm{SM}=$ Notasi untuk sepeda motor

\section{Kebisingan}

Menurut Keputusan Menteri Lingkungan Hidup No 48 Tahun 1996, kebisingan adalah bunyi yang tidak diinginkan dari usaha atau kegiatan dalam tingkat dan waktu tertentu yang dapat menimbulkan gangguan kesehatan manusia dan kenyamanan lingkungan. Menurut Suma'mur (2009), bunyi atau suara didengar sebagai rangsangan pada sel saraf pendengaran dalam telinga oleh gelombang longitudinal yang ditimbulkan getaran dari sumber bunyi atau suara dan gelombang tersebut merambat melalui media udara atau penghantar lainnya, dan manakala bunyi atau suara tersebut tidak dikehendaki oleh karena mengganggu atau timbul diluar kemauan orang yang bersangkutan.
Menurut Keputusan Menteri Negara Tenaga Kerja No:Kep-51/men/1999, kebisingan adalah semua suara yang tidak dikehendaki yang bersumber dari alat-alat proses produksi dan atau alat- alat kerja yang berada pada titik tertentu dapat menimbulkan gangguan pendengaran.

\section{Jenis-jenis Kebisingan}

Berdasarkan asal sumbernya, kebisingan dapat diklasifikasikan menjadi 5 macam kebisingan, yaitu (Setiawan, 2014):

1) Kebisingan kontinyu dengan spektrum frekuensi luas (steady state, wide band noise), misalnya suara yang ditimbulkan oleh kipas angin.

2) Kebisingan kontinyu dengan spektrum frekuensi sempit (steady state, narrow band noise), misalnya suara yang ditimbulkan oleh kipas gergaji sirkuler dan katup gas.

3) Kebisingan terputus-putus (intermitten), misalnya suara lalu lintas, suara kapal terbang dilapangan udara.

4) Kebisingan impusif (impact or impulsive noise), misalnya suara tembakan atau meriam.

5) Kebisingan impulsif berulang, misalnya suara yang ditimbulkan mesin tempa.

\section{Sumber Kebisingan}

Menurut Subaris dan Haryono (2008) sumber kebisingan dibedakan menjadi tiga yaitu: (1) bising industri, (2) bising rumah tangga, (3) bising spesifik. Kebisingan berdasarkan letak sumber suaranya, dibagi menjadi dua yaitu: (1) bising interior, merupakan bising yang berasal dari manusia, alat-alat rumah tangga atau mesin-mesin gedung yang antara lain disebabkan oleh radio, televisi, alat-alat musik, dan juga bising yang ditimbulkan oleh mesin-mesin yang ada di gedung tersebut seperti kipas angin, motor kompresor pendingin, pencuci 
piring dan lain-lain. (2) bising eksterior, bising yang dihasilkan oleh kendaraan transportasi darat, laut, maupun udara, lalu lintas, industri, alat-alat mekanis yang terlihat dalam gedung, tempat-tempat pembangunan gedung, perbaikan jalan, kegiatan olahraga dan lain-lain di ruangan atau gedung.

\section{Standar Baku Mutu Kebisingan}

Berdasarkan Peraturan Menteri Kesehatan No.718.MEN.KES/PER/XI/1987 tingkat kebisingan dibagi atas zona lingkungan yang terdiri dari empat zona, yaitu: (1) Zona A: intensitas $35-45$ dBA yang diperuntukkan bagi tempat penelitian, rumah sakit, tempat perawatan kesehatan dan sosial dan sejenisnya. (2) Zona B: intensitas 45 - 55 dBA yang diperuntukkan bagi perumahan, tempat pendidikan, dan rekreasi. (3) Zona C: intensitas 50-60 dBA yang diperuntukkan bagi areal perkantoran, pasar dan perdagangan. (4) Zona D: intensitas $60-70$ dBA yang diperuntukkan bagi kawasan industri, pabrik, stasiun KA, terminal bis dan sejenisnya.

\section{Analisis Korelasi}

Menurut Sudjana (2005) koefesien korelasi (r) digunakan untuk mengukur kuat atau tidaknya hubungan yang terjadi antara variabel $\mathrm{X}$ dengan $\mathrm{Y}$, dimana nilai koefesien ( $\mathrm{r}$ ) berkisar antara -1 sampai dengan 1 .

Apabila ternyata nilai (r) mendekati 1, maka hubungan antara nilai $\mathrm{X}$ dan nilai $\mathrm{Y}$ dinyatakan kuat sekali dan analisis dilanjutkan dengan analisis regresi, untuk memperkirakan besarnya pengaruh variabel $\mathrm{X}$ terhadap variabel $\mathrm{Y}$, kemudian meramalkan nilai $\mathrm{Y}$ dengan menggunakan persamaan analisa regresi sederhana. Hubungan antara dua variabel $\mathrm{X}$ dan $\mathrm{Y}$ tidak selalu bersifat garis lurus (linear), tetapi bisa juga berupa garis lengkung (non linear).

$\mathrm{R}$ squared $\left(\mathrm{R}^{2}\right)$ merupakan angka yang berkisar antara 0 sampai 1 yang mengindikasikan besarnya kombinasi variabel independen secara bersama-sama mempengaruhi nilai variabel dependen. Semakin mendekati angka satu, model yang dikeluarkan oleh regresi tersebut akan semakin baik. Nilai $\mathrm{R}^{2}$ terletak antara 0,25 0,50 maka nilai koefisien kolerasi cukup, 0,50-0,75 maka nilai koefisien kolerasi sedang/cukup kuat, 0,75-0,90 maka nilai koefisien kolerasi kuat hubungannya dan 0,90-1,00 maka nilai koefisien kolerasi sangat kuat.

Jalan Suprapto Kota Bengkulu, merupakan salah satu jalan yang terpadat di kawasan Kota Bengkulu. Jalan Suprapto memiliki panjang \pm 850 meter dan memiliki 2 jalur, 4 lajur dan 1 median jalan. Peningkatan volume lalulintas terjadi pada jam 06.0007.30 WIB, jam 11.45-13.15 WIB dan jam 16.00-17.30 WIB. Mobilitas kendaraan yang padat di kawasan Jalan Suprapto menimbulkan kebisingan yang disebabkan dari kendaraan. Kondisi ini menimbulkan ketidaknyamanan bagi sebagian orang yang berada di fasilitas umum, perkantoran, pusat perbelanjaan, hotel, dan tempat ibadah.

Berdasarkan uraian di atas maka penelitian ini bertujuan untuk mencari pengaruh distansi terhadap tingkat kebisingan yang bersumber dari bunyi mesin kendaraan. Jaringan jalan yang digunakan merupakan jaringan Jalan Suprapto Kota Bengkulu. Analisis data difokuskan pada arus lalulintas puncak dan jarak pengamatan yang telah ditentukan. 


\section{METODE PENELITIAN}

Penelitian berlokasi di Jalan Suprapto, Kota Bengkulu. Survei arus lalulintas dilakukan selama 1 minggu dari hari Senin, sampai Minggu pada pukul 06.30-08.00 WIB, pukul 11.45-13.15 WIB dan 16.00-17.30 WIB dengan interval pengamatan 15 menit. Titik pengamatan terdiri dari 2 segmen jalan yaitu segmen 1 dengan lokasi tempat ibadah dan segmen 2 dengan lokasi fasilitas umum.

Parameter yang diamati adalah arus lalulintas dengan menggunakan alat perekam dan kebisingan dengan menggunakan sound level meter. Data kebisingan diukur selama 1,5 jam yang merupakan waktu arus lalulintas puncak dari hasil pengamatan selama 1 minggu. Untuk

setiap lokasi pengamatan, perekaman data kebisingan diambil 5 titik dengan interval jarak tiap $10 \mathrm{~m}$.

Hubungan antara jarak pengamatan dengan nilai kebisingan diukur dengan pendekatan model matematis, menggunakan persamaan regresi linier. Fungsi regresi linear mempunyai bentuk persamaan:

$y=a+b x$

Jarak pengamatan merupakan variabel bebas dan nilai kebisingan merupakan variabel tidak bebas.

\section{HASIL DAN PEMBAHASAN}

\section{Volume Lalu Lintas}

Kendaraan diklasifikasikan ke dalam tiga jenis kendaraan sesuai PKJI 2014, yaitu kendaraan berat $(\mathrm{KB})$, kendaraan ringan (KR), dan sepeda motor (SM). Jalan Suprapto tidak dilewati kendaraan berat (KB) sehingga pada penelitian ini hanya diambil kendaraan ringan (KR) dan sepeda motor (SM). Tabel 1 dan 2 adalah adalah hasil penelitian arus lalu lintas pada kondisi jam puncak lokasi pengamatan 1 dan 2 .

Tabel 1. Arus Lalu Lintas Jam Puncak Selama 1 Minggu Pada Lokasi Pengamatan 1.

\begin{tabular}{|c|c|c|c|c|c|c|c|}
\hline \multirow{2}{*}{$\begin{array}{c}\text { Waktu } \\
\text { Pengamat } \\
\text { an }\end{array}$} & \multicolumn{7}{|c|}{ Arus Lalu Lintas Satuan Kendaraan Ringan (skr) } \\
\hline & Senin & Selasa & Rabu & Kamis & Jum'at & Sabtu & Mlinggu \\
\hline $\begin{array}{c}07.45- \\
08.00\end{array}$ & 890 & 806 & 800 & 850 & 1.078 & 1.164 & 1.150 \\
\hline $\begin{array}{l}12.45- \\
13.00 \\
\end{array}$ & 1.480 & 1.416 & 1.346 & 1.306 & 1.274 & 1.382 & 1.320 \\
\hline $\begin{array}{l}17.15- \\
17.30\end{array}$ & 1.520 & 1.332 & 1.394 & 1.614 & 1.720 & 1.850 & 1.828 \\
\hline
\end{tabular}

Tabel 2. Arus Lalu Lintas Jam Puncak Selama 1 Minggu Pada Lokasi Pengamatan 2.

\begin{tabular}{ccc|c|c|c|c|c}
\hline \multirow{2}{*}{\begin{tabular}{c} 
Waktu \\
\multirow{2}{*}{$\begin{array}{c}\text { Pengamat } \\
\text { an }\end{array}$}
\end{tabular}} & \multicolumn{6}{c}{ Arus Lalu Lintas Satuan Kendaraan Ringan (skr) } \\
\cline { 2 - 8 } & Senin & Selasa & Rabu & Kamis & Jum'at & Sabtu & Minggu \\
\hline $\begin{array}{c}07.45- \\
08.00\end{array}$ & 1.078 & 1.086 & 1.206 & 1.236 & 1.288 & 1.336 & 1.304 \\
\hline $\begin{array}{c}12.45- \\
13.00\end{array}$ & 1.732 & 1.766 & 1.748 & 1.670 & 1.708 & 1.724 & 1.638 \\
\hline $\begin{array}{c}13.00- \\
13.15\end{array}$ & 1.412 & 1.494 & 1.654 & 1.562 & 1.552 & 1.638 & 1.596 \\
\hline $\begin{array}{c}17.15- \\
17.30\end{array}$ & 1.698 & 1.608 & 1.748 & 1.792 & 1.852 & 1.848 & 1.828 \\
\hline
\end{tabular}

Dari tabel 1 dan 2, menunjukkan bahwa puncak arus lalulintas terjadi pada waktu sore hari pada rentang waktu 16.00-17.30 WIB. Puncak arus lalu lintas maksimum adalah sebesar 1.828 skr yang terjadi pada hari Minggu pukul 17.15-17.30 WIB. Rentang waktu 16.00-17.30 WIB hari SeninJum'at pada umumnya adalah kondisdimana masyarakat pulang dari kantor menuju kediaman masing-masing. Sedangkan pada hari Sabtu-Minggu pada umumnya masyarakat sedang menikmati libur dan belanja.

\section{Intensitas Tingkat Kebisingan}

Pengukuran data kebisingan dilakukan pada pukul 16.00-17.30 WIB. Pemilihan waktu tersebut berdasarkan arus puncak lalu lintas yang didapatkan dari survei kendaraan. 
Survei kebisingan kendaraan dilakukan pada lokasi Pengamatan 1 dan 2, terdiri dari 5 titik dengan interval jarak 10 meter tegak lurus dari tepi jalan. Tabel 3 adalah hasil pengukuran kebisingan pada lokasi pengamatan 1 dan 2, sedangkan Gambar 1 adalah nilai kebisingan rata-rata dari 2 lokasi pengamatan.

Berdasarkan Tabel 3 dan Gambar 1 nampak bahwa nilai kebisingan berkurang dengan semakin jauh jarak titik pengamatan dengan ruas jalan. Pada jarak $10 \mathrm{~m}$ dari tepi jalan, didapatkan nilai kebisingan rata-rata sebesar 68,8 dBA dan pada jarak $50 \mathrm{~m}$ nilai kebisingan rata-rata sebesar 55,5 dBA. Berdasarkan penjelasan tersebut dapat dikatakan bahwa semakin jauh jarak titik pengamatan dari sumber bunyi, maka intensitas kebisingan semakin menurun.

Tabel 3. Nilai Kebisingan Lokasi Pengamatan 1 dan 2.

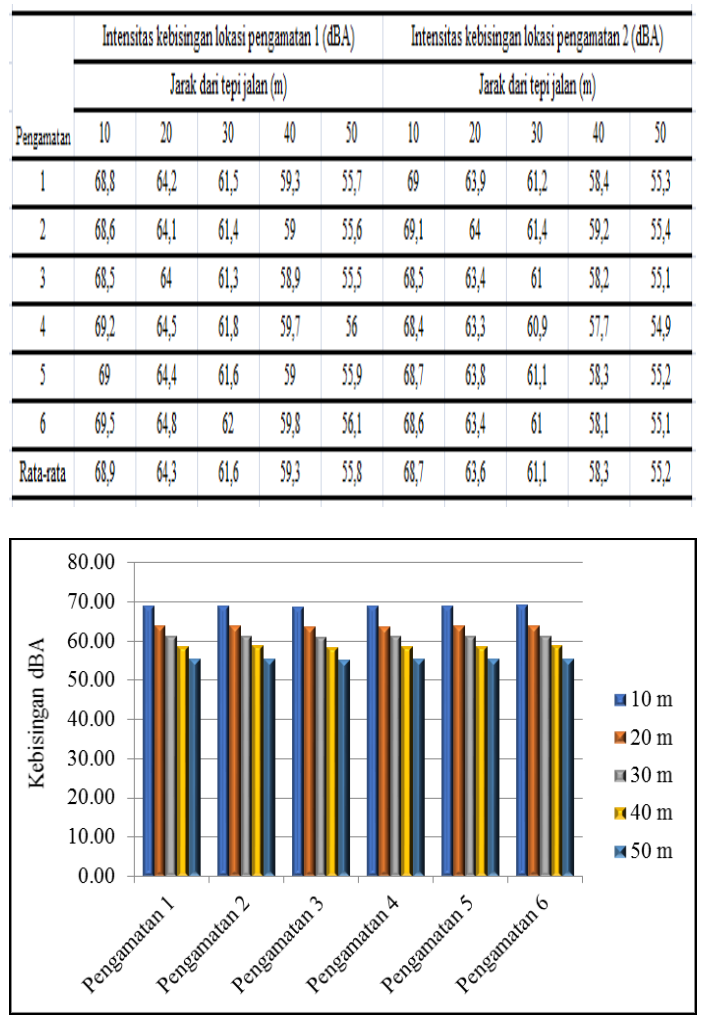

Gambar 1. Intensitas Kebisingan RatarataJalan Suprapto Kota Bengkulu

\section{Model Regresi Linier}

Model regresi linier dan nilai korelasi antara jarak pengamatan dengan tingkat kebisingan pada Jalan Suprapto Kota Bengkulu disajikan dalam Gambar 2.

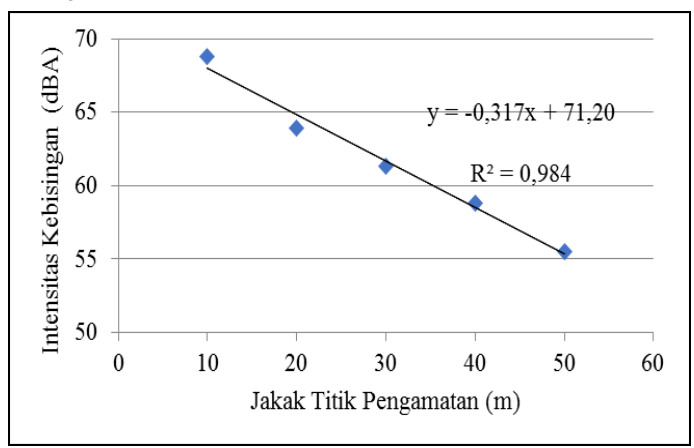

Gambar 2. Model Regresi Linier dan Nilai Korelasi Antara Jarak Pengamatan dengan Tingkat Kebisingan

Model regresi linier dari hasil penelitian memiliki persamaan $y=-0,317 x+71,20$ dengan nilai koefisien $\mathrm{R}^{2}$ adalah sebesar 0,984 . $\mathrm{Y}$ adalah variabel tidak bebas yang menunjukkan besaran intensitas kebisingan dan $\mathrm{x}$ adalah variabel bebas yang menunjukkan interval jarak pengamatan diukur dari tepi jalan Suprapto Kota Bengkulu. Nilai $\mathbf{R}^{2}$ sebesar 0,984 memiliki arti bahwa jarak obyek dari sumber bunyi berpengaruh sangat kuat terhadap besaran intensitas kebisingan yang diterima.

Menurut Peraturan Menteri Kesehatan RI No.718.MEN.KES/PER/XI/1987, untuk areal perkantoran, pasar dan perdagangan, baku mutu tingkat kebisingan yang disyaratkan maksimal berada pada rentang 50-60 dBA. Dengan menggunakan persamaan regresi linier $y=-0,317 x+71,20$ jarak aman terhadap gangguan kebisingan kendaraan pada Jalan Suprapto Kota Bengkulu berada pada rentang 35-70 m dari tepi jalan. 


\section{KESIMPULAN}

1. Kesimpulan yang dapat diambil dari penelitian ini adalah sebagai berikut:

2. Arus puncak lalu lintas yang melewati ruas Jalan Suprapto Kota Bengkulu sebesar 1.828 skr terjadi pada hari Minggu pukul 17.15-17.30 WIB.

3. Model regresi linier dari hasil penelitian memiliki persamaan $\mathrm{y}=-0,317 \mathrm{x}+71,20$ dengan nilai koefisien $\mathrm{R}^{2}$ adalah sebesar 0,984 .

4. Jarak aman terhadap gangguan kebisingan kendaraan pada Jalan Suprapto Kota Bengkulu berada pada rentang 35-70 m dari tepi jalan.

\section{DAFTAR PUSTAKA}

Abbas, S. 2008. Manajemen Transpotasi. Graha Ilmu. Yogyakarta.

Direktorat Jenderal Bina Marga. 2014. Pedoman Kapasitas Jalan Indonesia (PKJI). Direktur Pembinaan Jalan Kota. Jakarta.

Keputusan Menteri Negara Tenaga Kerja. 1999. Keputusan Menteri Negara Tenaga Kerja No:Kep-51/men/1999 tentang Nilai Ambang Batas Faktor Fisik Ditempat Kerja. Sekretariat Negara. Jakarta.

Keputusan Menteri Lingkungan Hidup. 1996. Kepmen LH No 48 Tahun 1996 tentang Baku Tingkat Kebisingan. Sekretariat Negara. Jakarta.

Luttinen, R. T., 2004. Capacity and Level of Service at Finnish Unsignalized Intersection. Finnish Road Adminstrasion. Helsinki.

Peraturan Menteri Kesehatan. 1987. Peraturan Menteri Kesehatan Nomor 718/MEN.KES./PER/XI/1987 tentang Kebisingan yang Berhubungan dengan Kesehatan. Sekretariat Negara. Jakarta.
Setiawan, A. 2014. Studi Pengaruh Kecepatan dan Jumlah Kendaraan Terhadap Kebisingan Jl. Raya Prabumulih-Palembang $\mathrm{km} \quad 32$ Indralaya Sumatera Selatan. Jurnal Teknik Sipil dan Lingkungan. Vol. 2 No. 4.

Subaris dan Haryono. 2008. Hygiene Lingkungan kerja. Mitra Cendika. Yogyakarta.

Suma'mur. 2009. Hiegiene Perusahaa dan Keselamatan Kerja. Sagung Seto. Jakarta.

Sudjana. 2005. Metoda statistika : untuk bidang biologi, farmasi, geologi,industri, kedokteran, pendidikan, psikologi, sosiologi, teknik, dll. Tarsito, Bandung.

Tamin, O. Z., 2000. Perencanaan dan Permodelan Transportasi. Penerbit ITB. Bandung.

---.2009. Undang-undang No. 22 Tahun 2009 Tentang Lalu Lintas dan Angkutan Jalan. Sekretariat Negara. Jakarta. 